Revista UNIMAR 18(1):85-98, 1996.

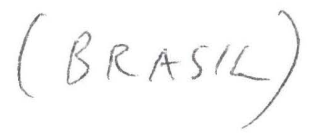

\title{
MALTESE LITERATURE UNDER THE KNIGHTS OF ST. JOHN (1530-1798)
}

\section{Oliver Friggieri*}

\begin{abstract}
The article provides a brief systematic account of the literary activity of Maltese and foreign writers in Malta under the Knights of St. John (1530-1798). It starts with establishing the nature and extent of the Italian literary tradition in the island and the ways in which local writers participated in the literary life of neighbouring Italy. The recognition of the presence of epic sentiment is given due consideration since the epic form is one of the major poetic genres discussed. The paper also seeks to identify the relationship between Maltese, the older native tongue, and Italian, the main and almost exclusive medium of literary expression during the period.
\end{abstract}

Key words: Maltese literature, Maltese language, epic, Italian tadition.

\section{A LITERATURA MALTESA SOB OS CAVALHEIROS DE SÃO JOÃO (1530-1798)}

RESUMO. Este artigo pretende ser um relato breve e sistemático da atividade literária de escritores malteses e estrangeiros em Malta no período da ocupação pelos Cavalheiros de São João (1530-1798). A natureza e a extensão da tradição literária italiana na ilha e as maneiras pelas quais os escritores nativos participaram da vida literária da Itália são analisadas. O reconhecimento da presença do épico é extensivamente estudado porque a forma épica é um dos maiores gêneros literários discutidos. Procura-se também identificar o relacionamento entre o maltês, a antiga língua nativa, e o italiano, o meio principal e quase exclusivo para a expressão literária durante este período.

Palavras-chave: Literatura maltesa, língua maltesa, épico, tradição italiana.

Department of Maltese, University of Malta, Malta.

Correspondence to Oliver Friggieri.

Data de recebimento: 07/07/95.

Data de aceite: $17 / 08 / 95$. 


\section{INTRODUCTION}

It has always been expected that the presence of the Order of St. John would consolidate and develop the cultural tradition already existing among the educated classes in Malta. The fundamental aspect was, of course, Christianity, namely a religion which also assumed the role of national identification. In many respects this tradition tended to simplify matters which had nothing to do with faith in itself. The older spoken language, Maltese, an originally Arabic dialect going back to the Arab occupation (870-1091), had no written or recognized culture of its own and was in principle identified with illiteracy. It was only in the late 18th century that it started to gain the respect of the intelligentia and to be used for literary purposes on an ever-widening scale. Christianity and Latinity, two terms which by themselves are too imprecise to denote anything specific, actually embody the more evident features of the island's cultural identity. The Order of St. John, therefore, had no added problems of a strictly cultural nature when it arrived in Malta and established itself as the sole protagonist in both political and cultural affairs. It could easily insert itself within the pre-existent pattern of behaviour and thought and further enhance it by attracting the attention of Maltese men of culture.

\section{THE ITALIAN CULTURAL TRADITION}

One of the eariier Italian documents in Malta goes back to 1409 when Franciscu Gattu was elected mayor and ambassador of the island with the aim of relating on official matters with the king of Aragon and Sicily. Umberto Biscottini published excerpts from this document: " $\mathrm{Li}$ capitoli facti et ordinati per la universitati di la chitati it insula di Malta, dunati et assignati a lu nobili misser Franciscu Gattu..." Another document is dated 1419. The Spanish domination favoured to a great extent the birth and development of a proper Italian tradition. This is known to us through documents of significant importance, among which a memorandum of 1419 which was presented by the Government of Malta to the Viceroy of Spain in Sicily "per domandare l'erezione di una torre nell'isolotto di Comino tra Malta e Gozo in difesa delle due isole contro le scorrerie dei saraceni." 2

The oldest register of the Maltese commune for the year 1469 includes a list of prices fixed by the noble jurors for objects on sale: "In 
primis la carne de lu beccu crastratu, de la capra, de lu porcu..."3 Together with Latin, Italian was also the official language of the Church. The archives at the Mdina cathedral are written in these languages. In Italian are written all the historical inscriptions of the era and "le numerose liste di arrivi e partenze di merchantili con $i$ rispettivi carichi." 4

During the whole epoch characterized by the domination of the Order of St. John the same tradition continued to develop in the said direction since Malta, a feudal dependency of Sicily, conceded to the Knights by Charles V, "visse all'interno della sfera culturale italiana, e italiana fu perciò la sua letteratura fino all'avanzato Ottocento." The use of Italian included internal and official communications. For instance, the laws of the Order were presented in Italian. ${ }^{6}$ The manuscripts of the Council of the Knights fall within the same pattern.

Italian was also used on special occasions when the high officials of the Order and the Maltese people met together for some official celebrations. When the first stone of the city of Valletta was laid in 1566, Padre Pelo Angosciola delivered a sermon in Italian in which he said: "Come speriamo nella bontà divina ella (la città) ha da essere, non solo fido riposo della Religione di San Giovanni Gerosolimitano, e fortezza sicura dell'isola di Malta, ma anche scudo alla Sicilia, riparo all'Italia". ${ }^{7}$ A partial explanation of this phenomenon may be found in the fact that the Grandmasters "si consideravano sempre principi di un paese italiano; ... si preoccuparono di curare particolarmente 1o studio dell'italiano nelle scuole maltesi e nell'università da loro fondata, e favorirono in ogni modo lo scambio di uomini e di idee fra le loro isole e 1'Italia." 8

These few examples are only meant to prove that the official cultural tradition was not exclusively linguistic, but went far beyond the level of formal communication, representing a particular vision of a social and political way of being. This general approach included various modes of collaboration between Maltese, Italians and Sicilians. For instance, the introduction of printing in Malta is connected with Pompeo di Fiore, probably a Sicilian, who brought to the island all the necessary material to open the first printing press (1642). Some time later Paolo Bonacota was granted permission to do likewise. ${ }^{9}$ 


\section{ACADEMIC AND CULTURAL SOCIETIES}

Friggieri

Cultural societies flourished in Malta mainly in the 19th Century. However, such a tradition is much older. The cultural revival, especially literary and historically, brought about by the advent of the Order which gave so much credit to the relationship between knowledge and military prowess, motivated many Maltese men of letters to dedicate themselves to culture and establish close links with the major, perhaps the only, recognised point of reference - the Italian world. Giovannantonio Ciantar (1696-1778) was member of the Accademia Reale delle Inscrizioni e Belle Arte of Paris, the Accademia degli Intronati of Siena, of the Colombaria of Florence and of the Arcadia of Rome. Following the trend of the times, he also assumed the names of Brillante and Tagindo Jonide in his capacity as member of the Florentine and Roman societies. ${ }^{10}$ Likewise the Maltese poet Luigi Rigord (1757-1823) assumed the name

of Ruidarpe Etolio on forming part of the Colonia Etnea. ${ }^{11}$
The tradition of Italian societies and academies was most formidable in the 15th century. One can only speculate on what the Maltese response to this phenomenon could have been since nothing is known of Maltese cultural societies prior to the 17th century. We know, however, that according to Ms 1 of the National Library of Malta, Ignazio Saverio Mifsud founded the Accademia Fervida in 1743. ${ }^{12}$ Mifsud thus provided Maltese intellectuals with the opportunity of participating in learned manifestations and discussions modelled on what used to happen in
Italian organisations:

"Il nome di Accademia dei Fervidi non può non richiamarci alla mente altri nome simili di accademie italiane, come quella degli Accesi di Reggio Emilia ... o come quella degli Infiammati di Padova... Nel discorso inaugurale dell'Accademia dei Fervidi, letto il 19 giugno 1743, il giovane fundatore retoricamente nel randava: 'Quanto or goder dovrebbe Malta l'invitta nel racchiudere in seno un'Accademia, con cui potrebbe vantarsi in egual modo, che i più insigni accademici di Malta assunsero anchéssi un nome accá I Fervidi Mifsud, per esempio, si chiamò Academicus Fertilis; il Fr. Antonio Dennis, Academicus Ingeniosus Fertilis; un Roberto Micallef, Academicus Profundus." 
Gian Francesco Agius de Soldanis (1712-1770), a well known researcher of the Maltese language and a friend of various Italian scholars, belonged to the Accademia Botanica e di Storia Naturale of Cortona and to that of the Apatisti of Florence and of the Erranti of Fermo. His friend Michel Angelo Grima (1731-1798) was himself also a member of these institutions and knew very closely Dr Ludovico Coltellini, secretary of the Cortona Accademy. ${ }^{14}$

The overall impression emanating from such activities is that literature was more looked at as an expression of knowledge of a relatively high order than as a unique and sublime expression of innermost feelings. A keen interest in the language, which was always Italian and only sporadically Maltese, together with a deep devotion towards the more recognised and esteemed Italian literary masters -(Petrarch, Dante, Ariosto) largely explains why such activities seem to have flourished so much, on the one hand, and why personal creativity is significantly rare, on the other. This should not imply that Maltese writers completely lacked a personality of their own, or that no instances of authentic literary merit can ever be found. On the other side of the fence, there was a popular, mainly spoken, literary tradition of the people who expressed themselves in what was up to then considered a mere dialect, unworthy of any proper literary recognition.

\section{EARLY WORKS IN MALTESE}

Some writers, however, have had the courage of trying their hand in Maltese. Their experiments are now part of the earlier period in the history of Maltese literature, which had to wait for the Romantic revival to assume the role of a widely diffused means of expression.

An important example of poetic expression in Maltese is Lill-Gran Mastru Cottoner written around 1675 by Giovanni Francesco Bonamico (1639-1680). This poem which survived owing to the interest of de Soldanis in the Maltese language, ${ }^{15}$ was first published in $1931 .^{16}$ Bonamico wrote extensively in Latin and Italian but seems to have been attracted for once by the beauty of the spoken language of the Maltese and consequently sought to infuse in his experimental piece the literary and thematic characteristics he would derive from his own Italian education. Such a synthesis of lexical and syntactical features of an originally Arabic origin and of stylistic and intellectual aspects of the 
main currents of Italian tradition was subsequently bound to prevail in all the Maltese authors writing in Maltese.

Bonamico is highly influenced by Baroque. Antithetical statements, hyperboles and an almost ritualistic approach to the theme expressing respects towards a political figure are all elements which will invariably characterise Maltese poetry of a popular or semi-literary nature in the late 18th and early 19 th centuries. An interesting compromise is already made between the Maltese oral tradition of the ghana (popular country songs) and literary poetry patterned on the most typical aspects of the Italian tradition. For example, the rhyme scheme, the use of the eight syllable metre called ottonario and the quatrain are basic points of contact. As time went by, more Maltese men of letters discovered the beauty of the Maltese language and introduced into the new literary tradition all the more important components they had previously known and utilised in their so-called Italian experience.

Other early examples which illustrate this fundamental intercourse between an old oral popular tradition and the sophisticated Italian modes of poetry writing are particularly numerous in the 18 th century. I will mention only those which I consider more important from a historical and literary aspect and which I collected in the first volume of my $\mathrm{Il}$ Ktieb tal-Poezija Maltija: Francesco Wzzino: Lil Sant'Anna (1730), LillGlorjuz Arkanglu San Mikiel (1741); Gian Francesco Agius de Soldanis (1712-1770): Sonetto punico-maltese in onore dell'illmo. signr. Dr. Ludovico Coltellini (1758); Anon: 1749 - Fuqek Nithaddet Malta (18th
Century, prior to 1759).

\section{THE EPIC MOTIVE}

It may be relatively easy to explain why the older spoken language of the Maltese had to wait for so long to acquire any minimal recognition on the official cultural level and to assume the role of a primary, if not major, medium of literary expression. It is by far easier to identify the reason why the epic motive, so widely diffused in the Italian tradition
universally followed by all Maltese writers in the period 1530-1779, is
almost completely absent or only expressed in almost completely absent or only expressed in disguise. With the arrival of the Romantic movement numerous writers tried to give vent to this repressed sentiment, but they could do this only in accordance with the contemporary trends which by then transformed the epic sentiment into 
lyricism. Consequently, Maltese literature, written in both Italian and Maltese, can hardly be said to include any semblance of a proper epic tradition, in spite of the fact that its ancient history has been constantly considered as a fundamental source of inspiration. The lyrical form and the historical novel, therefore, were later supposed to fill in this substantial gap and according to literary modes which in no way substitute the epic form.

One can presumably conclude that in the period under review the spirit of nationalism or ethnic and territorial integrity and identity was not sufficiently strong. In spite of the fact that the literary tradition in Italian is quite long in Malta, it could not really give shape to the innermost feelings and aspirations of a people still in search of a proper definition. Foreign domination, therefore, is more efficient than the flourishing of culture. Maltese writers lacked a sufficient degree of selfconfidence, or perhaps, it was too early for them to predict what the main currents of European culture were to be with the advent of Romanticism. The earliest interest in Maltese was philological, and the solitary figure of Mikien Anton Vassalli (1764-1829) was a real exception. His spirit was radically ahead of his times for the island. In the Discorso preliminare, published as an introduction to his Ktyb $y l$ Klym Malti (1796), he outlines a detailed programme for the rehabilitation of his country, both politically and culturally, and provides an excellent account of the language problem, which he considers the primary cause of all the cultural evils prevailing at his time in the island. But, again, we are only referring to the final years of the Order in Malta, a period which had in store a fundamental change in the historical and cultural experience of the island. Henceforth, writers will really start following the contemporary trends of European culture and assert rights and aspirations in manners nowhere to be found in the previous centuries. At the centre of all this massive movement of national reconstruction there was the real acquisition of self-awareness, directly attributable to the discovery of a whole spate of national traditions, particularly the Maltese language.

In retrospect, therefore, the absence of any deeply radicated national sentiment in literary expression is only a sign of the times. Within this context reference to an epic about Malta written by an Italian writer residing in the island can attain particular significance. Il Valletta is perhaps one of the most intriguing literary works ever to be written in Malta. Bartolomeo dal Pozzo, a poet born in Verona in 1637 , spent a 
long time in Malta where he became well acquainted with its history and spiritual identity. It was Giannantonio Ciantar who accurately prepared the manuscipt for printing. The work, however, did not come to light until $1915 .{ }^{17}$ The epic is a real tribute to the achievements of the Order of St. John and easily manages to incorporate the aspirations of both the rulers and the ruled. Highly descriptive, rich in its lexical stock and modes of narration, Il Valletta forms part of the modern epic tradition.

Pozzo was vested as a knight at St. Catherine's church, Valletta, in 1656 and stayed in Malta till 1698, when he obtained permission from Grandmaster Martin de Redin to return to his country, where he died in 1722. He wrote Il Valletta between 1670 and 1675. Laurenza summarises the plot and its motives as follows: "Eroe principale è il La Vallette, che molto somiglia Goffredo e al pius Aeneas; eroi secondari sono Ugo Cotoner, foggiato sul Rinaldo della Gerusalemme [Liberata], Filippo Lascaris e il giovane Parisot. All'azione principale, per mezzo di episodii e di digressioni più o meno opportune, s'intrecciano altre imprese e gesta illustri dei cavalieri. La verità storica, como'è da prevedersi, vieni spessissimo dal poeta sacrificata". ${ }^{18}$ Laurenza believes that dal Pozzo patterned his work on Virgil, Ovid, Tasso, Ariosto and Dante, and may be related to the epic cycle inspired by Tasso's Gerusalemme Liberata, where the encounters between Christians and Turks constitute the central plot. It is equally comparable with Chiabresa's Amedeide, Sarrocchi's
Scanderbeide and Graziani's Conquista di Granata.

From the start Tasso's influence is particularly evident. Dal Pozzo's opening line " $L$ 'armi canto, e ' 1 campion che l'aspra guerra" closely echoes Tasso's "Canto 1'arme pietose e '1 capitano". Both of them, however, are equally indebted to Virgil who opens his Aeneid with the words "Arma virumque cano". Historical figures are developed alongside others which are purely fictitious; dramatic effect frequently relies on reference to divine intervention. In this respect he can be said to have exerted some influence on subsequent Maltese writers.

Dal Pozzo makes full use of the sound effects which can be derived from an adequate handling of the ottava rima. He is continuously in search of different words and his hendecasyllabic lines run smoothly and
are rarely conditioned by the rhyme scheme:

Sta giorno e notte il limitar patente,

$\mathrm{Ne}$ 'stridolo cancel l'adito preme;

Vengon le voci, e la magion frequente 
Le replica all'orecchio, e tutta freme:

$\mathrm{Ne}$ ' gridor, ma sommesso un suon si sente,

Come rotta fra scogli onda che geme:

Lungi bandita è la quiete, e basso

resta il silenzio, e por non v'osa il passo.

Perhaps the most important work published by a Maltese writer in the $1530-1779$ period is Madre di Dio $(1762)^{19}$ by Giovannantonio Ciantar (1696-1778). This long work, dedicated to Grandmaster Manoel Pinto de Fonseca, is made up of nine volumes written in hendecasyllabic lines. It is a sort of Christian epic which can somehow justify the idea that the lack of a developed traditional awareness could not logically lead to the creation of a properly defined epic, though the feeling involved has to find an analogous means of expression. On the other hand, Maltese writers who were so deeply influenced by the Italian epic tradition could not so easily ignore the fact that the epic genre and epic motives were important segments of the literary mainstream of the era.

Ciantar ignores Maltese history and turns to faith, or directly to Theology, to derive his inspiration which in the process will soon assume an apparently 'political' character. Facts and sentiments, episodes and motives are partly dealt with humanely, and the intentionally religious aspect frequently plays second fiddle. The poet is epic for all intents and purposes, but ambiguously so, since he regularly humanises what is divine and vice-versa. Madre di Dio is somewhere between a theological treatise and a historical saga. Ultimately it is none, since the poet is equally interested in relating the human world to eternity. Perhaps his imaginative strategy suits him in his efforts to identify a point of contact between religious principles and truths, on the one hand, and known classical modes of writing poetry, on the other. His intentions are too overtly literary to help him transform technical devices into real poetic effect. His technique is too dependent on the most important models in the modern epic tradition to guarantee a sufficient degree of spirituality. But this is probably the most interesting aspect of the whole work. It equally betrays a literary attitude which will prevail in subsequent writers. Religion is historically perceived, and history is transformed into a series of events wherein divinity is bound to play the central role. In a sense, this also reflects the dualism or ambiguity of the Order of St. John itself, partly religious and partly political. The intimate relationship which both components of life in Malta have assumed later on can be directly traced to this trend. 
In his introduction Ciantar states that he was motivated by the love which Tuscan poets have shown towards the Blessed Virgin. He himself wanted to write a long poem modelled on the rules typical of the epic, since this was the best way of following the Horatian principle of unifying utility with pleasure. He was equally afraid that the inclusion of secondary episodes could easily hamper the constant flow of events and narration could subsequently suffer. Considering that the central motive is sacred or moral, this could have a negative effect on the utilitarian or educational aspects of the work. It seems that Ciantar is at a loss on how to follow the Aristotelian rules of unity and how to insert minor plots or episodes without reducing the importance of the central religious theme.

However, dogma and other truths of religion are in no way given secondary importance, even though they are frequently used to further enrich the narrative process and are bound to fall within the scheme of the epic pattern. Long, detailed descriptions resolve themselves into intervals wherein the poet can immediately put on show his technical ability. He himself declares that he makes full use of means of surprise, "anzi anche più di quello che fanno gli epici con le loro spiritose invenzioni; imperciocchè in vece de' Portenti inventati dalla loro fantasia, il mio leggitore troverà qui de' veri prodigi operati dall'autore della Graziae della Natura." Instead of false deities, he claims to have given the pride of place to God himself, to angels and other spirits who serve him in heaven. Theology, therefore, has substituted imagination, even though now theology itself is treated imaginatively.

Madre di Dio is a highly ambitious work and is spread over about four hundred pages. Religious arguments are all organised and put in a particular order, almost resembling a logical exposition of identifiable historical facts. However, it is more the end-product of an intellectual or a scholar than of a poet. Knowledge is more determinative than imagination, though the latter is continuously fused into the former. Ciantar is constantly in search of drama and grandeur of all sorts, but episodes frequently betray their abstract origin. It will be superfluous to point out that the poet is grossly influenced by Baroque poetry and by various types of Mannerism:

Preser poscia congedo: e a la vicina

Città sen giro per cercarvi albergo:

E la trovaro in una casa, in cui

Stettero insieme; e tutti i lor discorsi 
Eran di ciò, ch'avean veduto in quella

Grotta beata, o Paradiso in terra:

$E$ in rammentarlo i lumi lor due fonti

Divenivan di pianto, e i loro cuori, Animati Vessuvi, ardean d'amore.

\section{OTHER EXAMPLES}

Much less significant is the poetic production of the 17 th Century. Geronimo Marulli's I natali delle religiose militiae de' Cavalieri Spedalieri, e Templari, e della Religione del tempio l' ultima roina, published in 1643, provides examples of Dante's far-reaching influence. Two sonnets by Marulli and Carlo Cosentino are inspired by the general aspects which characterize Dante's Paradiso and Inferno respectively. Both resolve themselves in vignettes typical of so much poetic production of the era. Baroque influence is, however, very strong and seems to be the most important feature of both sonnets, themselves samples of a trend which historically gave birth to an age-long tradition in Malta.

Enrico Magi, born in 1630, is perhaps the most interesting poet of his time. His Dafne, a pastoral fable in five acts, forms an integral part of contemporary tradition and closely participates in the stylistic and thematic features of the movement known as Arcadia. Magi maintains a musical tonality throughout and what may be initially seen as complex human problems is immediately developed into serene, almost jovial situations wherein man is depicted as the arbiter of his own destiny. His Rime is another important example of the great influence Baroque poetry had on local production. Instances of such influence are not alien to Dafne, though the latter is essentially conceived as a long song with varying moods:

Non si deve temer alcuna forza

D'amorosa saetta, se non quando

Di propria volontà ne' tesi lacci

Ciechi troppe inciampiamo.

Amor è cieco e, senza forza essendo,

Vuol caricar di fragil arco il tergo. 
Maltese literature in Italian in the 17th century, however, is mainly distinguished by historical research. Descrittione di Malta isola nel mare siciliano (1647) by Giovanni Francesco Abela (1582-1655) is a landmark in the island's cultural tradition. Carlo Micallef, who died in $1689,{ }^{20}$ deserves a particular mention for his novel L'Ismeria o sia l'allegrezza della Francia nei stupori dell'Egitto. Essentially Baroque in conception, structure and style, it has a special place in the history of Maltese narrative prose. Equally important is Disavventure marinaresche, an adventure story by Fabrizio Cagliola (1604-1665), a member of the Order of St. John. The novel, published as an edition of Malta Literaria in 1929, is a real trend-setter for Malta. Cagniola already classifies his characters in believers and non-believers, and the whole narrative is a fusion of historical data and imaginative content.

\section{THE ROMANTIC REACTION}

A systematic history of Maltese Literature, in Italian and in Maltese, during the period of the Order of St. John has still to be written. In my historical research on the island's literary tradition in the native tongue I have dwelled at length on the international dimension of a supposedly internal phenomenon. Romanticism introduced a radically different vision of both life and literature, and one can really speak of a new era, especially where national awareness and the fundamental components of national identity are zoncerned. Malta's literary itinerary prior to the proper discovery of Maltese $s$, however, very significant for its causative effect on subsequent modes of vriting. It constitutes a secure point of reference for the establishment of the rinciple of historical continuity. It also provides examples of a tradition igainst which the new literary movement was to react most forcefully, at east to assert the basic tenets of democracy and to identify literature with the ssential characteristics and aspirations of a whole national community.

\section{NOTES}

Cathedral Archives, MS. A, p. 171-176, published by A. Mifsud, "Malta al sovrano nel 1409". Confer also A. Mifsud, La cattedrale e l'università, ossia il comune e la Chiesa in Malta, 1917, p. 39-40; U. Biscottini, "Il volgare a Malta ed una questione dantesca", in Il giornale di politica e di letteratura, X, vol VI, 1934, p. 665-670. 
2 Cini, p. 17.

3 Malta National Library, Ms II, Univ. (1450-1498), $27 \mathrm{v}$ and 28 r. Also Laurenza (1924), p. 13.

4 Patti, p. 171.

5 Mangion, p. 285.

${ }^{6}$ Cini, p. 19

7 Abela, p. 12

8 Di Pietro, p. 5.

9 Confer E. Parnis, Notes on the First Establishment, Development and Actual State of the Printing Press in Malta, Government Printing Office, 1916.

${ }^{10}$ Laurenza (1932), p. 86; Pullicino, pp. 77 and 99.

${ }^{11}$ Laurenza (1924), p. 16.

${ }^{12}$ Laurenza (1932), p. 86.

${ }^{13}$ Laurenza (1932), p. 86.

${ }^{14}$ Pullicino, pp. 83-85.

${ }^{15}$ de Soldanis, Ms. 144.

${ }^{16}$ Cremona, p. 3

${ }^{17}$ Dal Pozzo, p. 10.

${ }^{18}$ Dal Pozzo, pp. 11-12.

19 The whole title of the edition is Vita della Madre Santissima di Dio Maria sempre Vergine descritta in verso sciolto.

20 According to I.S. Mifsud, (p. 287) Micallef held high positions in the Order and the Church. He is the author of various works on the Order. Mifsud states that the novel was the first work ever printed by Paolo Bonacota, whereas the second and the third editions were published in Venice and Viterbo respectively.

\section{REFERENCES}

ABELA, G.F. Descrittione di Malta. Malta: P. Bonacota, 1647.

BISCOTTINI, U. Il volgare a Malta ed una questione dantesca. Il Giomale di politica e di letteratura.

CIANTAR, G.A. Vita della Madre santissima di Dio Maria sempre Vergine descritta in verso sciolto. Malta: Stamperia di sua Altezza Seremissima, 1762.

CINI, A. Origine e progresso della lingua italiana in Malta. Malta: Tipografia del Malta, 1931.

CREMONA, N. Tifkirijiet ewlenija ta' tqabbil malti. Lehen il-Malti 7(1), 1931. 
DAL POZZO, B. Il Valletta - poema eroico inedito del Seiscento in XII Canti tratto dal MS 168 della Biblioteca Pubblica di Malta. Malta: Tipografia Nazionale, 1915.

DE SOLDANIS, G.F. Agius. Nuova scuola della antica lingua punica scoperta nel moderno parlare maltese e gozitano. Malta: National Library, Ms. 144.

DI PIETRO, A. La presenza dell'Italia a Malta. Il Ponte 1(apr.), 1965.

LAURENZA, V. La questione del metodo negli studi letterari e la letteratura italiana in Malta. Malta: Stamperia del Governo, 1924.

LAURENZA, V. Società culturali in Malta durante il settecento e l'ottocento. La Brigata. 4(1), 1932.

MANGION, G. Giovan Francesco Buonamico, scienzato e letterato maltese del seicento. Studi seicenteschi, 12(1), 1971.

MIFSUD, A. La cattedrale e l'università, ossia il comune e la Chiesa di Malta. La Diocesi 7(2): 39-40. 1917.

MIFSUD, A. Malta al sovrano nel 1409. La Diocesi, 8(2):243-248, 1918.

MIFSUD, I. S. Biblioteca maltese. Malta: Stamperia di sua Altezza Serenissima, 1764.

PATTI, G. I cento giorni di Garibaldi in Sicilia nel giornalismo maltese. Messina: Editrice La Sicilia, 1972.

PULLICINO, G. Cassar. Kitba u kittieba tal-Malti. Malta: Università ta' Malta, 1962. 

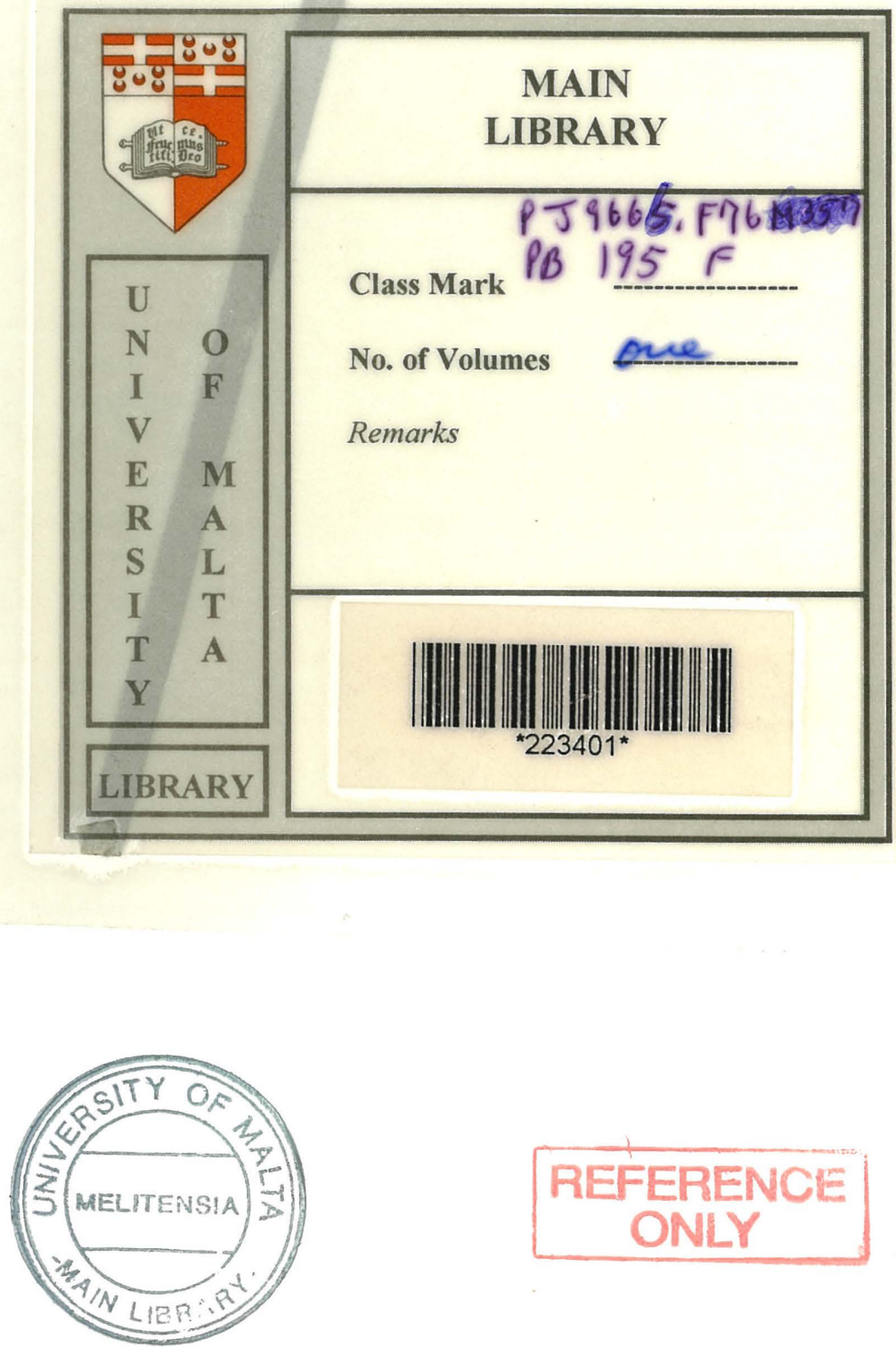
